UDC [159.922.6-053.4]:82'23

DOI: $10.52534 / \mathrm{msu}-\mathrm{pp} .7(2) .2021 .25-37$

Nataliia V. Kharchenko*, Inna V. Mysan

Hryhorii Skovoroda University in Pereiaslav

08401, 30 Sukhomlynskyi Str., Pereiaslav, Ukraine

\title{
Psycholinguistic Study of the Speech of Older Preschool Children: Specific Features of Understanding the Figurative Meaning of Phrases and their Use in Spontaneous Speech
}

\section{Article's History:}

Received: 11.03.2021

Revised: 02.05.2021

Accepted: 10.06.2021

\section{Suggested Citation:}

Kharchenko, N.V., \& Mysan, I.V. (2021). Psycholinguistic study of the speech of older preschool children: Specific features of understanding the figurative meaning of phrases and their use in spontaneous speech. Scientific Bulletin of Mukachevo State University. Series "Pedagogy and Psychology", 7(2), 25-37.
Abstract. The acquisition of native language phraseology is important for the speech and mental development of preschool children, because with the help of phraseology children can expressively reproduce a variety of social events in speech, impartially characterise people, their actions and deeds. The purpose of the study was to investigate psycholinguistic features of children's development of operations of understanding figurative meaning of phraseological expressions and their verbalisation in speech. To this end, the authors used methods of assessing the understanding of figurative meaning of proverbs and metaphors, direct interpretation of a word, choosing one variant of meaning from several paraphrases, interviewing children, recording their statements on a voice recorder, and talking to children. The analysis of children's speech was carried out according to the criteria and corresponding indicators: semantic (lexical, metaphorical, conceptual), pragmatic (active use of phrases, correct reproduction, appropriateness of actualisation), expressive-stylistic (evaluative, emotional, figurative speech). Four levels of children's operations of understanding figurative meaning of phraseological expressions and their use in speech were identified: high, sufficient, average, low, each of which correlated with certain psychological and psycholinguistic characteristics. It was found that children acquire phraseology spontaneously, under the influence of the speech of others, and selectively. It has been revealed that preschool children understand the meaning of phraseological units better than they use them in oral speech; the use of phraseological units in spontaneous speech is a more complex speech operation for children than the operation of decoding the figurative meaning of a phraseological unit. However, both the operations of understanding the figurative meaning of phraseological units and the operations of verbalising phraseological units in spontaneous speech require further development. The practical value of the research lies in the development of a diagnostic technique for studying the operations of understanding figurative meaning of phraseological expressions and their use in spontaneous speech in the zone of a child's speech activity and thinking development

Keywords: understanding of figurative meaning of phraseological units, explication of phraseological units, speech learning, phraseological units

\section{INTRODUCTION}

At the present stage of the development of psychological science, issues related to the study of the peculiarities of the functioning of phraseological units in the utterances of preschool children have become relevant. Researchers of children's speech (O.M. Gvozdev, L.O. Kalmykova, I.V. Mysan, V.K. Kharchenko, S.N. Zeitlin, etc.) believe that phraseological units not only normalise children's language, but also improve speech culture and make the expressions of pre-schoolers more eloquent, and above all involve children in the origins of national culture, folk art, folk wisdom, presented in accurate, witty and colourful means of expression of the native language - phraseological 
expressions. The importance of phraseology for speech and mental development of children is that with their help it is possible to expressively reproduce various social events, to neutrally characterise people, their actions and deeds in speech.

Analysis of scientific research on the problem of children's knowledge of phraseological structures showed that this problem is the subject of attention of psychologists around the world. Thus, children's understanding of the figurative meaning of phraseologisms have been studied by Eastern European scholars [4-6]. Sensitivity to the emotional colour of speech is described in detail by O. M. Gvozdev [1]. The scientist is convinced that a child is able to express emotions in speech, using means of emotional expression such as phraseologisms, a variety of affectionate words, voice intonations, etc. N. Yeliseyeva, E. Guts, and A. Marin [7] studied the peculiarities of understanding phraseological expressions in the age period from middle school age (4 years) to middle school age (12 years) by Russian-speaking children who develop normally. Scientists have found that such a cognitive ability as the understanding of phraseologisms, slowly develops in early childhood. By the age of 6 , children mostly interpreted phraseology in the literal sense. By age 7 , the ability to correctly understand the meaning of phraseology increased until it reached a plateau at age 12 .

In Western European and American psychological science, this issue has been studied on the basis of various national languages by many scholars [8-10]. Researchers have identified factors that affect the ease of understanding of phraseologisms, among which are familiarity with phraseologisms [9-11]; semantic analysis of words that form phraseologisms [12-14]; the context in which the phraseologism is used [15]. The research of scientists [16-18] established the important role of working memory in the perception and understanding of phraseological expressions of 6-year-old children.

The research on the selected issue was organised from the standpoint of psycholinguistic science. Its purpose is to study the state and psycholinguistic features of the development of operations of understanding the figurative meaning of phraseological units and their use in spontaneous speech in children of older preschool age. The reason for this study was that so far, the vast majority of scientific research on this subject matter has been performed in the paradigm of cognitive psychology. According to the authors, the issue of psycholinguistics of children's phraseology (perception and understanding of the meaning of phraseology and their verbalisation in spontaneous speech) requires in-depth study. The choice of the age category of children - older preschool age - is due to the fact that it is at this age that pre-schoolers actively develop internal speech, which plays an extremely important and special role in such speech activities as listening (verbal perception and understanding of speech) and speaking [19]. As shown in the study of T.V. Akhutina [20], internal speech takes an active part both in listening (where a transformation of objective linguistic meanings into semantic structures (situational meanings) happens) and in speech (transformation of previously formed semantic structures into objective linguistic meanings takes place). In the senior preschool age, children begin to comprehend figurative meanings of words, they intensively develop verbal-logical thinking, perception, imagination, memory, which are directly related to speech; pre-schoolers learn to verbally explain thoughts, feelings, intentions, desires, beliefs, judgments in figurative, colourful, emotionally expressive speech. Children of this age are able to adequately perceive and express emotionality and evaluation, which are important components of the structure of phraseological meaning. In particular, they are able to evaluate everything around them, expressing their evaluation through emotional means of speech; they begin to dynamically actualise the evaluative and explanatory functions of the word [21]. At this age, the parameters of expressive features, differentiation, and generalisation of expression are improved. Verbal functions play a significant role in the mechanisms of the development of recognition and understanding the emotions [22]; children understand words and stable phrases that express emotions, are able to recognise emotional states, explained by means of words and expressions [23]. In older pre-schoolers, according to O.M. Gvozdev [1], V.K. Kharchenko [3], the interest in new colourful expressions - phraseologisms - significantly increases; they listen to unusual phrases, ask adults what they mean, try to use them in their own speech.

The object of this study - the process of speech development of older preschool children. The subject of the study - the state and psycholinguistic features of the development of operations of understanding the figurative meaning of phraseological units and their explication in oral spontaneous speech in children. The purpose of this study was to analyse the psycholinguistic features of the development in children of operations of understanding the figurative meaning of phraseological units and their verbalisation in the spontaneous speech of children at the preschool stage of ontogenesis (5-5; 5 years).

\section{MATERIALS AND METHODS}

The empirical study is based on scientific concepts and terms, which in their unity formed the theoretical basis of diagnostic methodology. Among them are:

- phraseologisms - stable combinations of two or more words, which are reproduced as vocal verbal formulas with semantic integrity in the process of speech, convenient for the conversational style of everyday communication and speech [24];

- phraseologisms, as a scientific category, should be studied not by "elements", but by "units", i.e., as linguistic, psycholinguistic, and psychological units. As linguistic units, phraseologisms are correlated with language, language standard, i.e., with the language system and language norm objectively present in people's "social memory"; these are codified language units. As psycholinguistic units, phraseological units are operative speech units correlated with speech activity: units of individual listening (verbal perception and understanding of the meaning of phraseological units) and individual speaking (use of phraseological units in spontaneous speech). As psychological units - phraseologisms are a reflection in the child's mind of the structure of 
language ability - psychophysiological speech organisation, which provides the implementation of various types of speech activities - listening (perception and understanding of the meaning of phraseologisms) and speech (use of phraseologisms in spontaneous speech) [25];

- analysis of the processes of perception and understanding of the meaning of phraseologisms and their use in oral speech should be carried out by operations, taking into account the peculiarities of speech operation as the smallest unit that contains all the properties of the whole spontaneity, unconsciousness, involuntariness [23];

- figurative meaning of phraseologism - a secondary lexical meaning that functions simultaneously with the direct (nominative, denotative), but in different styles. It arises on the basis of different types of associative connections and is connected with the main, leading meaning by relations of metonymic, metaphorical dependence, or certain associative features;

- acquisition of the figurative meaning of phraseologisms the process of acquiring a secondary, derivative meaning of phraseologism as a result of the development of operations of perception and understanding of the meaning of phraseology, and operations of using phraseological compounds in a spontaneous speech to nominate an object or phenomenon that is not its usual or natural referent;

- understanding the figurative meaning of phraseology - thinking and speech operation of abstraction from the direct (primary) meaning of the phraseological expression and the separation of its figurative (secondary) meaning.

Based on these provisions, the criteria and indicators for identifying the state and levels of development of children's operations in understanding the meaning of phraseologisms and their use in spontaneous speech are identified.

1. Semantic criterion - provided an opportunity to identify the degree of acquisition of the semantics of phraseologisms (understanding the figurative meaning of phraseologisms). Indicators: lexical - the development of operations for understanding the semantics of direct (literal) meaning; metaphorical - the development of operations of understanding the phraseological (secondary) meaning; conceptual - the development of operations of understanding the concept of phraseologism.

2. Pragmatic criterion - to study the state of development of operations for using phraseologisms in spontaneous speech. Indicators: activity in the use of phraseologisms; correct reproduction of phraseologisms; the relevance of the actualisation of phraseology in a given communication situation.

3. Expressive-stylistic criterion - to study the modality of speech associated with the expressive features of the phraseologisms used. Indicators: speech value; emotionality of speech; figurativeness of speech.

According to the semantic criterion, the state of development of children's operations of understanding the figurative meaning of phraseologisms was studied. For this purpose, primarily psycholinguistic methods were used, in particular: a) the method of assessing the understanding of the figurative meaning of proverbs and metaphors [19]; b) the method of direct interpretation of the word [19]; c) the method of choosing one variant of meaning from several paraphrases [12]. Such methods as interviewing, recording their statements on a voice recorder, conversations with children were also used.

The use of the method of assessing the understanding of the figurative meaning of proverbs and metaphors, and the method of direct interpretation of the word made it possible to investigate not only the state of development of speech operations in children but also mental ones. If the child understands the figurative meaning of phraseologisms, then he has developed abstract thinking; if the child has difficulties and understands phraseologisms in the literal sense, he has dominant figurative thinking. The quality of the interpretation of phraseologisms was also assessed: attention was focused on whether children focus on the essential features of the content of phraseologisms (full explanation of the figurative meaning of phraseologism), or explanations are vague and unclear. In addition, the presence of direct (denotative, nominative) interpretation of the meaning of words that form a phraseologism was clarified.

The study of psycholinguistic features of children's understanding of the figurative meaning of phraseologisms was carried out individually with each child. The diagnostics were made in the form of a game "Help the Bear to unravel unusual expressions". The course of the game is as follows. The educator (psychologist) addressed the child: "Look, our Bear is crying. Do you know why? He likes to listen to stories, fairy tales. But when he listens to them, he hears many unusual expressions that he does not understand. And because Bear does not understand these unusual expressions, he cannot fully understand what they are talking about. Let us help the Bear and explain these unusual expressions. How do you understand the expression...?" Incentive material: like snow on the head; to chase two rabbits; thick as thieves; loosen the tongue; to stand gaping; to twiddle one's thumbs; like the fifth wheel to a cart; keep one's mouth shut; a drop in the ocean; to lead around by the nose.

The experiment also provided such a variant of the task, when the child had difficulty in decoding the meaning of phraseologism; the child could not decipher the figurative meaning of the phraseologism (or was silent at all, or explained the meaning of the phraseological expression on the basis of random associations). It was important to find out the reasons for these difficulties. For this purpose, the method of "choosing one interpretation from the presented variants of definitions" was used [12]. According to this method, children were offered 2-3 readymade explanations of the meaning of phraseologism, from which they had to choose one that revealed the figurative meaning of phraseologism they heard.

For example, the phraseologism "like snow on the head" is correct in the following interpretation: it is about something that happened unexpectedly, suddenly. An additional option: in autumn the leaves fall from the trees like snow on the head; like snow on the head. The correct explanation of the phrase "Keep one's mouth shut" is "keep quiet, not a single word". Additional options: so that no one sees the tongue, it must be held by the teeth; 
when you communicate with people you should not show your tongue, but keep it behind your teeth. What did this method make it possible to study? First, what are the difficulties for children: in understanding the figurative meaning of phraseologism, or in the verbal explication of understanding. Secondly, it was assumed that a child who does not understand the figurative meaning of phraseologism, that is, thinks specifically, will not be able to choose from the given meanings of the actual figurative, and will focus on secondary, is vague.

The results of the diagnostics were processed as follows: children's answers were evaluated on a four-point scale from 0 to 3 points ( 3 points - a child interprets the figurative meaning of the phraseologism correctly; 2 points a child gives an adequate, close to the correct interpretation, description of the phraseologism; 1 point -explains the meaning of phraseologism incorrectly; 0 points - a child does not communicate). A maximum number of points - 30 . The state of development of operations of understanding the meaning of phraseologisms (by semantic criterion): 26-30 points - fully developed; $17-25$ points - partially developed; $8-16$ points - minimally developed; 0-7 points undeveloped.

According to the pragmatic criterion, the state of development of operations of explication of phraseological units in spontaneous speech in children was studied. For this purpose, the observational method was used on the speech of children in different life situations. In addition, they recorded whether children use phraseologisms when they are given a speech task, such as retelling a fairy tale or story, come up with a text story, text-description, and so on. The results of the diagnostics were processed as follows: children's speech was evaluated on a four-point scale from 0 to 3 points on indicators: a) activity of use ( 3 points - a child uses phraseologisms in speech actively and independently (without the requirements of a psychologist or educator); 2 points - a child uses phraseologisms in speech mostly at the request of the educator or in the process of retelling a fairy tale; 1 point - the child does not use phraseologosms in speech provided that educator had reminded to do so, but only in the process of retelling a fairy tale; 0 points - no phraseologisms in speech); b) correctness of reproduction (3 points - the child grammatically correctly reproduces phraseological units without changing the canonical form; 2 points - in reproduction of phraseological units the child sometimes assumes changes in their canonical form (but in the process of retelling a fairy tale phraseological units are reproduced correctly); 1 point - in the reproduction of phraseologisms a child tends to transpose and reduce; 0 points - a child does not use praseologisms in speech, even in the case of retelling a fairy tale); c) appropriateness of use ( 3 points - a child appropriately (according to the life situation, communication situation) actualises phraseologisms in speech; 2 points - a child mostly actualises phraseologisms in speech, but sometimes in spontaneous speech inappropriate use of phraseologisms is assumed; 1 - a child inaproppriately uses phraseologisms in both stimulated and spontaneous speech; 0 points - a child does not use phraseology). A maximum number of points - 9. The state of development of operations of use of phraseological units in speech (according to the pragmatic criterion): 8-9 points - operations are fully developed; 5-7 points - partially developed operations; 2-4 points minimally developed; 0-1 point - undeveloped.

According to the expressive-stylistic criterion, the operations of stylistic-expressive manifestation of children's speech were studied. For this purpose, the method of observation of spontaneous expressions of pre-schoolers was used. The results of the diagnostics were processed as follows: children's speech was evaluated on a four-point scale from 0 to 3 points on indicators: a) evaluation ( 3 points the child actively uses phraseologisms in speech, can give either positive or disapproving characteristics of the subject, situations using 9-10 phrases ("a bear stepped on his ear", "a wolf in sheep's clothing", "sharp tongue", "sharp eye", "kind heart", "hare soul", "to act against one's conscience", "keep silent like a fish in water", "be at the tail end", "loosen the tongue"); 2 points - a child gives either a positive or disapproving description of the subject, using 5-8 phrases; 1 point - a child gives either a positive or disapproving description of the subject, using 2-4 phraseologisms; 0 points - a child either gives a positive or disapproving characterisation, using 1 phraseologism or not using at all); b) emotionality (3 points - the child actively uses 9-10 phraseologisms in speech to convey emotional states ("heart is soothed", "heart aches", "finger licking good", "with a sincere heart", "with a dear soul", "eager to", "hair is standing up", "in the seventh heaven", "to push one's buttons", "to keep one's chin up"); 2 points - the child uses 5-8 phraseologisms in speech to convey the emotional state, 2 points - the child uses 2-4 phraseologisms in speech to convey an emotional state, 1 point - the child uses 1 phraseologism in speech to convey an emotional state, or does not use phraseologisms in speech at all); c) figurativeness (3 points - the child actively uses 9-10 phraseologisms in speech with wordsconcepts (for example: "beautiful as a red viburnum", "fear like the plague", "trong as an oak", "bypass the tenth road", "like pears on willow", "burn as a steady flame", "grow like a willow by the water", "like fire", "happy as a bird", "at the call of the heart"); 2 points - the child uses 5-8 phrases in utterances; 1 point - the child uses $2-4$ phrases in speech; 0 points - the child uses 1 phraseologism with wordsconcepts in speech, or does not use at all). Processing of diagnostic results: maximum number of points - 9. The state of development of operations of use of phraseology in speech (by expressive-stylistic criterion): 8-9 points - fully developed; 5-7 points - partially developed; $2-4$ points minimally developed; 0-1 point - undeveloped. The points that children receive according to three criteria (semantic, pragmatic, expressive and stylistic) are presented in Table 1. 
Table 1. A table of points that children receive according to three criteria

\begin{tabular}{|c|c|c|c|c|c|c|}
\hline \multirow{3}{*}{ No. } & \multirow{3}{*}{ Criteria } & \multirow{3}{*}{ Units of measurement } & \multicolumn{4}{|c|}{$\begin{array}{l}\text { The state of development of operations of } \\
\text { understanding the meaning of phraseologisms and } \\
\text { their use in speech }\end{array}$} \\
\hline & & & $\begin{array}{c}\text { Fully } \\
\text { developed }\end{array}$ & $\begin{array}{l}\text { Partially } \\
\text { developed }\end{array}$ & $\begin{array}{l}\text { Minimally } \\
\text { developed }\end{array}$ & Undeveloped \\
\hline & & & \multicolumn{4}{|c|}{ P O I N T S } \\
\hline 1. & Semantic & $\begin{array}{l}\text { Operations of understanding } \\
\text { the meaning of phraseologisms }\end{array}$ & $30-26$ & $25-17$ & $16-8$ & $7-0$ \\
\hline 2. & Pragmatic & $\begin{array}{c}\text { Operations of using } \\
\text { phraseologisms in speech }\end{array}$ & $9-8$ & $7-5$ & $4-2$ & $1-0$ \\
\hline 3. & Expressive-stylistic & $\begin{array}{l}\text { Operations of evaluation, } \\
\text { emotionality, figurativeness of } \\
\text { speech }\end{array}$ & $9-8$ & $7-5$ & $4-2$ & $1-0$ \\
\hline
\end{tabular}

The maximum number of points according to three criteria - 48

The state of development of operations of understanding the figurative meaning of phraseologisms:

41-48 - fully developed;

28-40 - partially developed;

19-27 - minimally developed;

0-18 - undeveloped

Thus, the total number of points was calculated according to three criteria, after which the results were summarised and presented in the speech profile of each child on the level of development of operations in understanding the figurative meaning of phraseologisms and their use in spontaneous speech.

The observational experiment involved 178 children of senior preschool age (5-5.5 years), who attend preschool education institutions of Kyivska, Khmelnytska, Khersonska, and Cherkaska Oblasts of Ukraine. To ensure internal and external validity, the participants of the experiment were randomly selected to create simple random samples. The use of such a sample is based on the assumption that each member of the population is equally likely to be included in the sample. Before the study, permission was obtained from parents for their children to participate in the experiment. All parents, educators, psychologists were acquainted with the purpose of the study, its procedure, and programme.

\section{RESULTS AND DISCUSSION}

The analysis of the results of children's performance of tasks on the interpretation of the meaning of phraseological units according to the semantic criterion showed the following results: $7.4 \%$ of children explained the figurative meaning of phraseological units; $35.4 \%$ of pre-schoolers explained phraseology in the literal sense; $44.2 \%$ of respondents explained the meaning of phraseologisms through associative connections; $9.8 \%$ of pre-schoolers gave semantically abnormal answers; $3.2 \%$ of children did not communicate (Fig. 1).

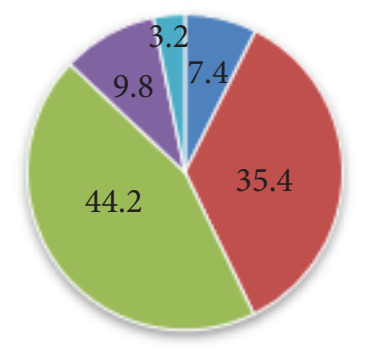

- Figurative meaning

- Explained through associative connections

- Did not communicate
- Literal meaning

- Semantically abnormal answers

Figure 1. The state of development of children's operations of understanding the direct and figurative meaning of phraseologisms

The experiment showed that $7.4 \%$ of children are able to explain the figurative meaning of phraseologisms. Although the children gave an incomplete description of phraseological conjunctions, it was close to the correct interpretation (children's statements are presented in an authentic form, with the preservation of syntactic, grammatical, orthoepic, and intonation features of their speech). For example: "Loosen the tongue" («Говорити», "Це балакать»). “То stare at the skies” («Не слухати»). "Jack of all trades” («Вихователька може зробити все $i$ 
сонечко вирізати», «Він всіх тічить», «Майструє руками», «Він все будує все», «Він робить щзось для усіх»).

The development of children's understanding of the figurative meaning of phraseologisms was indicated by the fact that they were able to decipher the secondary (figurative) meaning of this language unit, using examples from life experience. For example: "Like snow on one's head” («Це я не чекав щзось, а воно случилось, як ішов раз по вулиці, а з криші сніг ба-бах і мені прямо на голову»). "Keеp your mouth shut” («Як вихователька спитала мене, а я сховав язика за зубами, того щзо не хотів казати, хто скинув вазона з підвіконника, бо я не ябіда, і не хочу видавати друга»). The correct explanations of the secondary meaning of phraseologisms included such answers of children, in which they appropriately used examples from past life situations to reveal the meaning of phraseologisms. For example: “Thick as thieves” («Це ми так дружимо 3 Вальою, граємося, чергуємо разом»).

It was recorded that in the situation of the given variants of the meanings of phraseological units, the majority of pre-schoolers chose the figurative one faster and without any special difficulties. Why did this happen? Because children no longer needed to independently programme thoughts and explain them in a speech in the process of explaining the figurative meaning of phraseologism. They already had ready speech samples. Thus, the number of children who chose the figurative meaning correctly (from the proposed variants of meanings) increased compared to the number of children who could explain the figurative meaning of phraseologisms without the proposed variants of meanings. Thus, $20.4 \%$ of children chose the correct variant (figurative meaning of phraseologism), 59.4\% of children chose the direct meaning of phraseologism, $14.8 \%$ of pre-schoolers chose the associative variant of meanings, $4.1 \%$ of respondents chose the variant that revealed semantically abnormal meaning, $1.3 \%$ of children did not communicate (Fig. 2).

The ratio of the obtained results to the state of development of children's operations of understanding the figurative meaning of phraseologisms (without the proposed options) and in the situation of choosing the meaning of the given options is clearly shown in Figure 3.

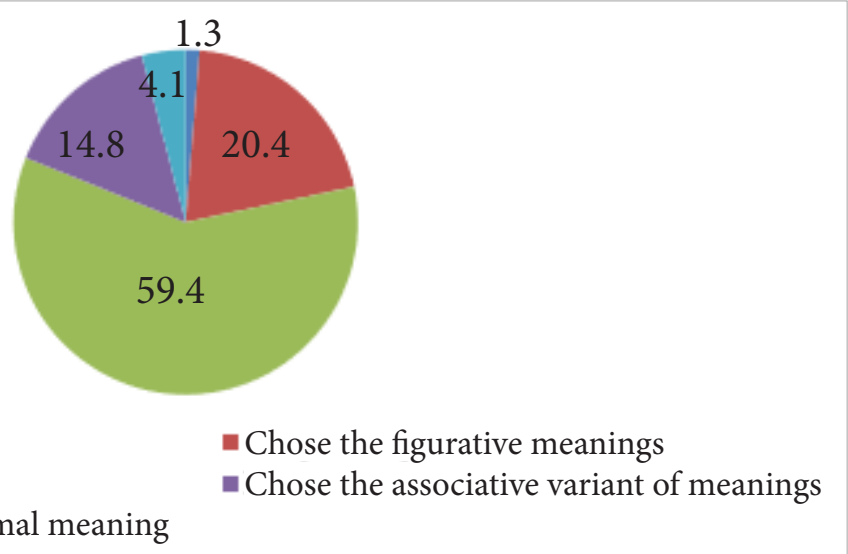

- Did not communicate

- Chose the direct meaning

n Chose the semantically abnormal meaning
- Chose the figurative meanings

Figure 2. Children's choice of figurative meaning of phraseological units from the given variants of meanings

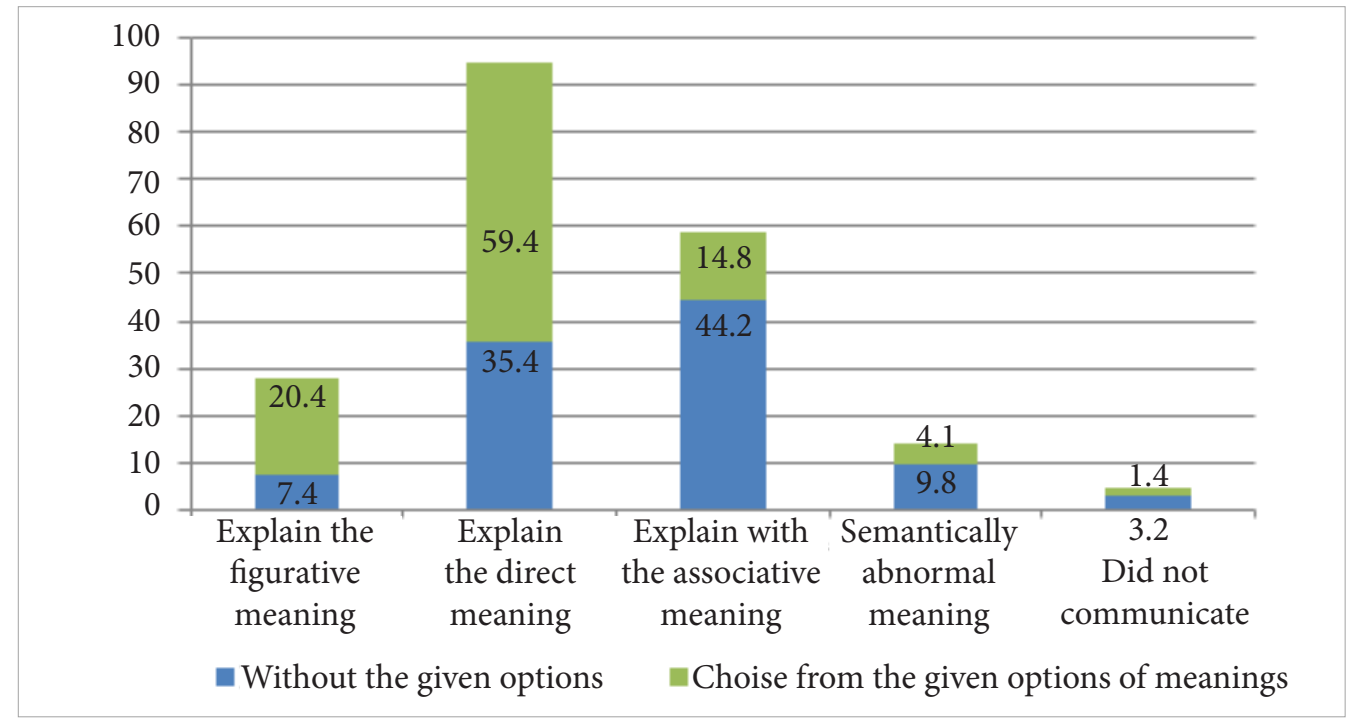

Figure 3. Children's understanding of the meaning of phraseologisms in situations without variants of meanings and with the given variants of meanings 
Thus, the study showed that children have an intuitive language ability to feel the general meaning of phraseologisms. However, it is difficult for them to explain this meaning without additional stimulation (answer options). In a situation of additional stimulation, some children are able to choose the correct option from the meanings - the figurative meaning of phraseologisms. Children with undeveloped operations of understanding the figurative meaning of phraseologisms gave explanations, which were classified (Table 2).

Table 2. Typology of mistakes made by children in the process of operationalising the meaning of phraseologisms

Ways of misinterpreting the meaning of phraseologisms

Typology of mistakes Incentive material Misinterpretations

I. Replacing the figurative meaning of the phraseologism with a direct meaning

\begin{tabular}{|c|c|c|}
\hline \multirow{4}{*}{$\begin{array}{c}\text { Through the tautology with } \\
\text { a violation of the structure of } \\
\text { allegory }\end{array}$} & $\begin{array}{l}\text { Як сніг на голову (like snow on } \\
\text { one's head) }\end{array}$ & «Він падає на голову», «Сніг падає на голову» \\
\hline & $\begin{array}{l}\text { Водою не розлити (thick as } \\
\text { thieves) }\end{array}$ & $\begin{array}{c}\text { «ести акуратно, щоб не розлити воду», } \\
\text { «вода не розливається із чашки» }\end{array}$ \\
\hline & $\begin{array}{c}\text { Тримати язика за зубами (to keep } \\
\text { one’s mouth shut) }\end{array}$ & $\begin{array}{c}\text { «Теба тренуватися всігда тримати язик } \\
\text { за зубами» }\end{array}$ \\
\hline & $\begin{array}{c}\text { П’яте колесо до воза (like a fifth } \\
\text { wheel to a cart) }\end{array}$ & «возає колеса» \\
\hline \multirow{2}{*}{$\begin{array}{l}\text { By replacing the idiom with } \\
\text { a lexical synonym with an } \\
\text { inaccurate figura-tive meaning }\end{array}$} & $\begin{array}{c}\text { Гнатися за двома зайцями (to } \\
\text { chase two rabbits) }\end{array}$ & «Бiгmu» \\
\hline & $\begin{array}{l}\text { Водою не розлити (thick as } \\
\text { thieves) }\end{array}$ & «Не хлюпатися у воді», «Кріпкі» \\
\hline \multirow{2}{*}{$\begin{array}{l}\text { By deriving the idiomatic } \\
\text { meaning only from the } \\
\text { denotative meanings of the } \\
\text { individual words of which it } \\
\text { consists, ignoring the context }\end{array}$} & $\begin{array}{l}\text { Як кіт наплакав (a drop in the } \\
\text { ocean) }\end{array}$ & $\begin{aligned} \text { «Кіт мявкає», «Коти не плачуть», «Ціле } \\
\text { море сліз» }\end{aligned}$ \\
\hline & Ловити гав (to stand gaping) & $\begin{array}{c}\text { «Собаку ловити», «Собака гавкає», «Собака } \\
\text { ловить другу собаку», «Собака гавкає, а } \\
\text { другий собака ловить гав» }\end{array}$ \\
\hline
\end{tabular}

\section{Interpretation of the meaning of idioms through associative meanings} of idioms with free phrases, words, and sen-tences with other seman-tic content
By replacing the meaning

Ловити гав (to stand gaping)

«Бути неслухняним, бігати, а коли мама каже, не слухатися їі», «Можна попитать включити телевізор і не сказати, будь ласка», "Байдикувати», "Нічого не робити», «Довго за комп'ютером сидіти, нічого не робити, не допомагати»

«Сніг на голову не можна, бо можна захворіти», "Бо він із криші упав і на голову» «Бо його собака укусила», «Бо його вдарив поганий хлопчик і він заплакав», «Котика хтось образив», "Больно йому»

Through cause and effect

Як кіт наплакав (a drop in the ocean)

Гнатися за двома зайцями (to chase two rabbits)

«Бо того щзо треба їх зловити»

«Бо треба зуби почистити», «Бо можна прикусити його і буде больно», "Бо зимою він замерзне, коли ти його не заховаєщ»

Тримати язика за зубами (to keep one's mouth shut)

Because of the formula-tion of the conditions in which the statement is contained

Як сніг на голову (like snow on one's head)

«Якщзо сніг падає на голову, то тоді болить голова»

«Щоб напитися», «Щоб принести воду мамі»

Through the formulation of the goal
Водою не розлити (thick as thieves)

Гнатися за двома зайцями (to chase two rabbits)

Тримати язика за зубами (to keep one's mouth shut) 


\section{Semantically abnormal answers-interpretations}

\begin{tabular}{|c|c|c|}
\hline \multirow{4}{*}{$\begin{array}{l}\text { Through the use of an adverb } \\
\text { that expresses (denotes) a sign } \\
\text { of measure, degree }\end{array}$} & $\begin{array}{c}\text { Розв'язати язика (to loosen the } \\
\text { tongue) }\end{array}$ & $\begin{array}{c}\text { «Нелегко», «Боязко якось», «Дуже легко», } \\
\text { «Бистро» }\end{array}$ \\
\hline & $\begin{array}{c}\text { Водити за носа (to lead around by } \\
\text { the nose) }\end{array}$ & «Акуратно», «Красиво», «Боляче», «Круто» \\
\hline & Ловити гав (to stand gaping) & $\begin{array}{c}\text { «Важко», «Інтересно», «Страшно», «Якось } \\
\text { недуже весело», «Дуже весело», «Дружно } i \\
\text { весело» }\end{array}$ \\
\hline & $\begin{array}{c}\text { Гнатися за двома зайцями (to } \\
\text { chase two rabbits) }\end{array}$ & «Бистро», «Псикольно якось», «Довго» \\
\hline \multirow{3}{*}{$\begin{array}{c}\text { Через висловлювання, } \\
\text { побудовані на спробах } \\
\text { простого відгадування } \\
\text { змісту фразеологізмів }\end{array}$} & $\begin{array}{c}\text { Водити за носа (to lead around by } \\
\text { the nose) }\end{array}$ & $\begin{array}{c}\text { «Схватити за носа і водити по коридору», } \\
\text { «Врач дивиться» }\end{array}$ \\
\hline & Ловити гав (to stand gaping) & $\begin{array}{c}\text { «Не слухатися маму», «Звуки якісь», } \\
\text { «Кдати щзось», «Прогулювати», «Не } \\
\text { робити цьього» }\end{array}$ \\
\hline & $\begin{array}{c}\text { Бити байдики (to twiddle one's } \\
\text { thumbs) }\end{array}$ & $\begin{array}{c}\text { «У барабани бити палками», «Бити палкою } \\
\text { по дереву» }\end{array}$ \\
\hline
\end{tabular}

According to the pragmatic criterion, the state of development of operations of phraseological units in spontaneous speech explication in children was studied. According to the results of the study, quantitative and qualitative data were obtained on the following indicators: activity of using phraseologisms; correct reproduction of phraseologisms; the relevance of the actualisation of phraseologisms (Fig. 4, 5, 6). It was found out how children reproduce phraseologisms in speech.

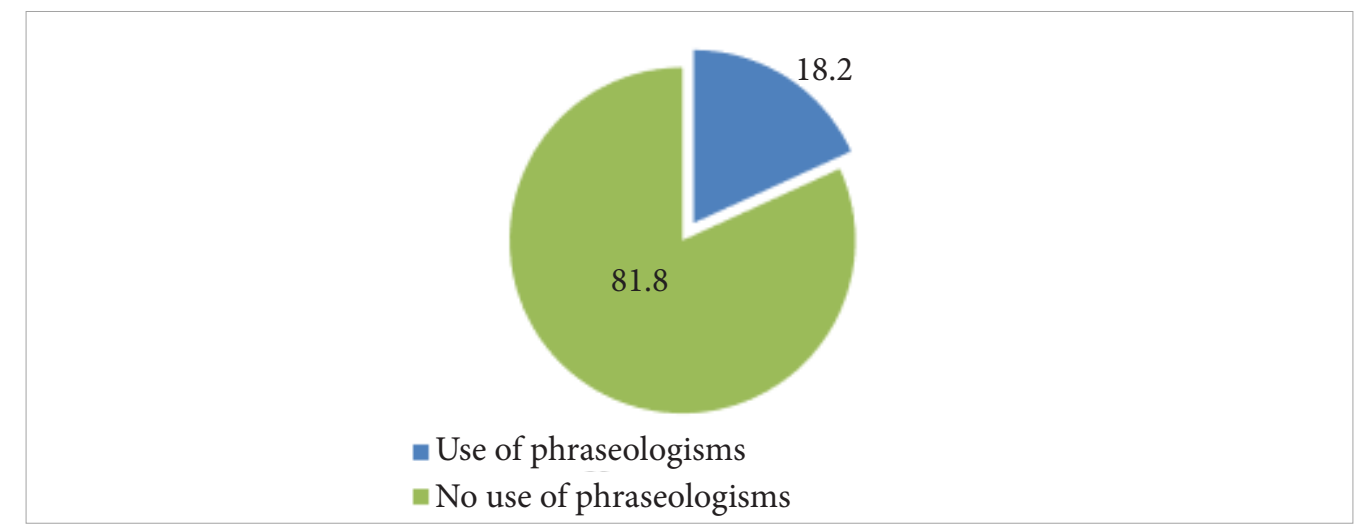

Figure 4. The activity of pre-schoolers' use of phraseologisms in spontaneous speech, $\%$

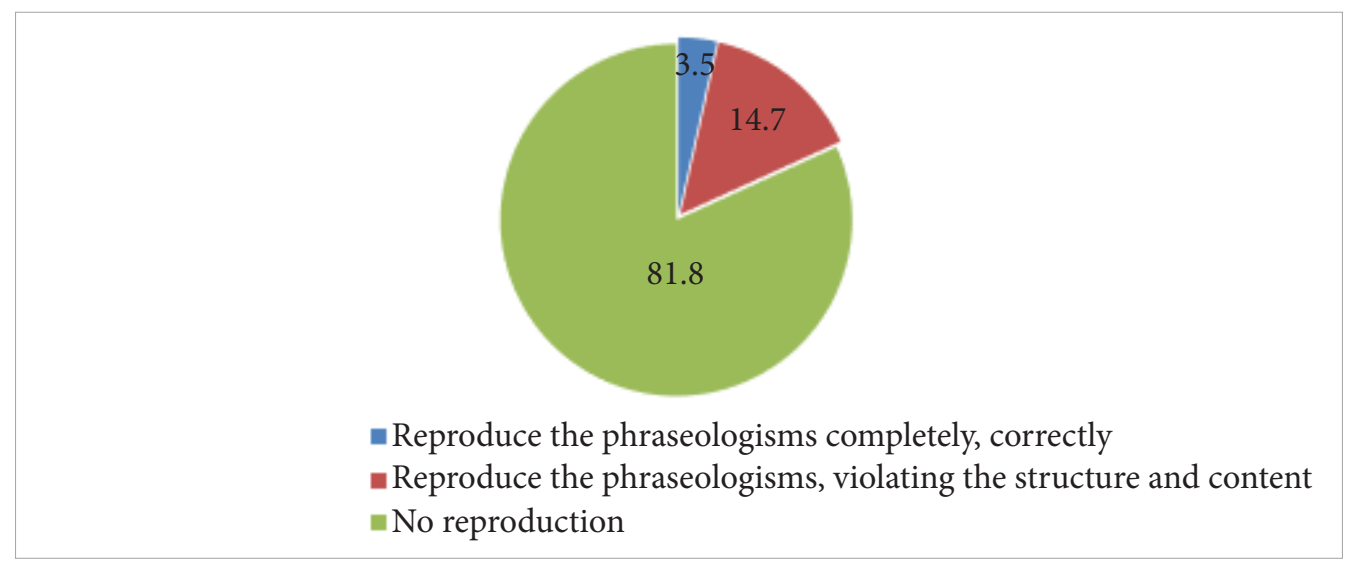

Figure 5. Correctness of reproduction of phraseological structures by children in spontaneous speech, $\%$ 


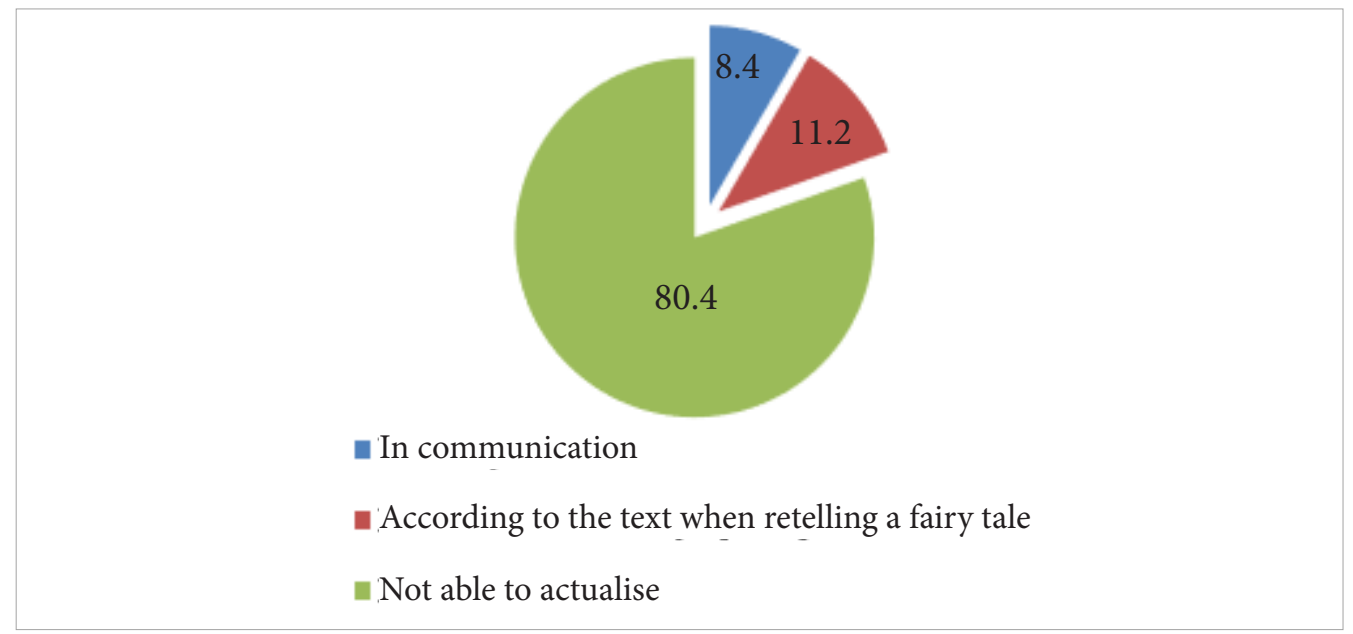

Figure 6. Relevance of children's actualisation of phraseological units in spontaneous speech, $\%$

The results of the analysis of the obtained data on the indicator "activity of the use of phraseologisms" showed that $81.8 \%$ of children have undeveloped operations of explication of any phraseologisms in speech. $18.2 \%$ of children used familiar phraseologisms with a certain frequency in their monologues (Fig. 4). So, when the teacher's assistant was setting the table, there were children who said: «Оие дивлюся, що вже їти насипають, так вже їсти схотілося, аж слинка вже котиться ("mouth is watering already")!» while waiting for dinner; when the children ate, Sasha L. repeatedly emphasised: «Сьогоднi така вкусна каша, аж у мене тящить за вухами ("tо wolf something down")!». In general, the most commonly used phrases that individual children used in speech in different situations were: "Leave alone", "To twiddle one's thumbs", "To know something in one's sleep", "The biter bit", "Cat and dog", "Keep your mouth shut".

Only $3.5 \%$ of children used phraseologisms correctly (according to the "correctness of reproduction" indicator). They reproduced phraseological expressions fully and accurately, without changing either their content or their form. That is, both in semantic and grammatical terms, phraseologisms remained unchanged (without transformations and reductions). $14.7 \%$ of children used phraseologisms in spontaneous expressions and at the request of the teacher, but modifying them in a way. For example: «3 ним компоту не заколотити» - instead of «3 ним каші не зварити» ("He is hard to deal with"), «Заховати язик $y$ зубах» - instead of «Тримати язика за зубами» ("То кеер one's mouth shut"), "Buтирати носа» - instead of «Bтерти Hoca" ("be one up on somebody") etc. $81.8 \%$ of children were not able to correctly reproduce the phraseologisms. Pre-schoolers changed their content, for example: «Buйmu мокрим із води» - instead of "Вийти сухим із води» ("To get off scot free"), «Bidnycmumu гав» - instead of «Гав ловити» ("To stand gaping"), "Дивитися крізь очі»instead of "Дивитися крізь пальиі» ("Close one's eyes to something") etc. The results of the analysis of children's speech on the indicator "correctness of reproduction of phraseologisms" are clearly presented in the figure (Fig. 5). According to the indicator "appropriateness of actualisation of phraseological units", it was found that $8.4 \%$ of children appropriately expressed phraseological units in both dialogue and monologue speech. $11.2 \%$ of children were able to accurately use phraseologisms when retelling a fairy tale (Fig. 6).

The study also revealed children who were not able to properly operationalise phraseologisms, because they did not understand the purpose of phraseologisms, did not understand in which situations you can one or that another expression, such as: "Так добре наївся, що аж слинки потекли» ("Mouth is watering already"), «Давай $з$ тобою будемо дружити, бо наші хати скраю і ми можемо ходити в садік разом» (“Out of one's hair") etc. (Fig. 6). Thus, low activity of children's use of phraseologisms in speech was recorded. Only $3.5 \%$ of children reproduced phraseological expressions in utterances completely correctly, trying to use phraseological units accurately in speech (mostly at the request of the educator), pre-schoolers violated the structure and changed the meaning of phraseological units.

According to the expressive-stylistic criterion, the state of development of operations of expressiveness of speech colouring in children was studied according to the following indicators: evaluation; emotionality; figurativeness (Fig. 7).

Thus, it is established that evaluation, being a qualitative characteristic of expressive speech, is manifested in children during the use of phraseological structures, but episodically and insufficiently or expressed. Thus, preschoolers have difficulty giving approving or disapproving characteristics to objects and things by means of phraseology. When children try to evaluate someone or something, it is an evaluation of their own actions, relationships, themselves. Notably, such assessments are mostly stylistically reduced, they are disapproving. For example: «Hу щзо $m u$, Віталька, молотиш язиком своїм, як ота мельниия?» ("to flap one's jaw"), "Давай помагай нам, Настя, а то знову сидиш, все байдики б”єщ» (“to twiddle one's thumbs”), «Ну чого ти не витерла куклу? Їі бридко у руки взяти!». Through the use of these phrases in speech in a certain context, pre-schoolers conveyed a negative attitude of peers' actions, condemned misbehaviour (7.7\% of children). However, there were also positive evaluations, admirations, expressed by means of phraseologisms, but these were singular, episodic, and individual cases of explication (3.5\% of children). For example: «Вова знає як треба машинку 
заводити як своїх n'ять пальиів» ("like the back of one's hand”), «Гарна сьогодні Маринка як квіточка, щьо біля нашого дома у клумбі росте» ("pretty as a picture"),
«Красивий Саша, як козачок». 4.9\% of children were unable to express evaluation in their own speech with the help of phraseology (Fig. 7).

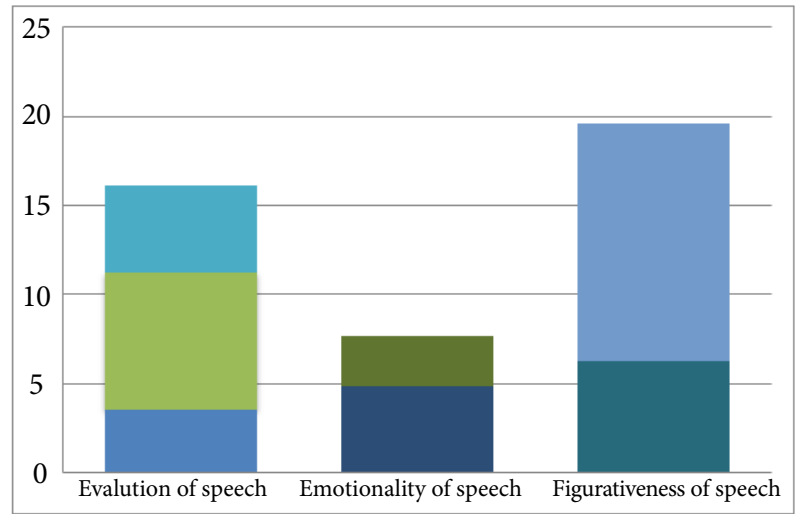

Lack of characteristics; 4.9

Disapproving characteristics; 7.7

Approving characteristics; 3.5

Negative emotions; 2.8

Positive emotions; 4.9

Lack of phraseological means in speech that create the figurativeness of speech; 13.3

Use of phraseological means that create the figurativeness of speech; 6.3

Figure 7. Experimental data on the development of operations of evaluation, emotionality, and figurativeness of speech as qualitative indicators of expressiveness of children's speech, $\%$

Pre-schoolers rarely expressed emotionality, emotional states (admiration, joy, surprise (curiosity), resentment, confusion) through phraseological units. For example: «Наталя Петрівна, а правда красиво у нас в групі? Аж душа padiє!» ("the heart fills with joy"), «Будy спати зараз без задніх ніг, бо втомився" ("sleеp like a baby"), "Не скажу, мама сказала, щоб я тримав язика за зубами, i не розказував нічого" ("kеер опе's mouth shut"). $4.9 \%$ of children expressed positive emotional states through phraseologisms, and $2.8 \%$ of pre-schoolers expressed negative emotions (Fig. 7). Thus, only in the speech of children who actively used phraseologisms, emotionally colored speech was traced. These were both in situations of independent explication of phraseological expressions in spontaneous speech, and situations of stimulation of their speech by the educator. In all these cases, the children reproduced the phraseologisms available in their speech and speech experience completely, correctly, and accurately, appropriately using phraseologisms in specific life situations, "fitting" them into the context of expression.

Figurativeness of speech is characteristic of children who showed the ability to understand the secondary meaning of phraseologisms in a situation where they were offered variants of meanings, as well as pre-schoolers who reproduced phraseologisms without making various changes (reduction, transformation), but in a situation where the educator encouraged them to use phraseologisms in speech. $6.3 \%$ of children used phraseological units that created the figurativeness of speech, but $13.3 \%$ of children did not use phraseological means in speech to ensure the figurativeness of speech (Fig. 7). This is confirmed both by children's understanding of the meaning of phraseological units offered to them for perception and by the actual facts of children's use of phraseological units in their own speech. Thus, the understanding and correct reproduction of phraseologisms already testify to the figurativeness of children's speech, created by means of both understandable and reproduced in speech with phraseologisms.

Analysis of observation results of the state of development of children's operations of understanding the figurative meaning of phraseologisms, as well as the use of phraseologisms in speech showed the uneven development of these operations, and also allowed to determine individual levels of completeness of relevant operations in children: high, sufficient, average, low (Table 3).

The different levels of development of children's operations of understanding the meaning of phraseologisms and their use in speech are graphically presented in Figure 8.

Table 3. Levels of development of operations of understanding the meaning of phraseologisms in children and their use in spontaneous speech

\begin{tabular}{|c|c|c|c|c|c|c|}
\hline \multirow{3}{*}{ No. } & \multirow{3}{*}{ Criteria } & \multirow{3}{*}{ Units of measurement } & \multicolumn{4}{|c|}{$\begin{array}{c}\text { Levels of development of speech } \\
\text { operations (\%) }\end{array}$} \\
\hline & & & \multicolumn{4}{|c|}{ POI N T S } \\
\hline & & & $48-41$ & $40-28$ & 27-19 & $18-0$ \\
\hline 1. & Semantic & $\begin{array}{l}\text { Operations of understanding the meaning of } \\
\text { phraseologisms }\end{array}$ & 7.4 & 35.4 & 44.2 & 13.0 \\
\hline 2. & Pragmatic & Operations of using phraseologisms in speech & 3.5 & 14.7 & 19.9 & 61.9 \\
\hline 3. & $\begin{array}{l}\text { Expressive- } \\
\text { stylistic }\end{array}$ & $\begin{array}{l}\text { Operations of evaluation, emotionality, } \\
\text { figurativeness of speech }\end{array}$ & - & 17.6 & 78.9 & 3.5 \\
\hline 4. & \multicolumn{2}{|c|}{$\begin{array}{l}\text { The average indicator of the development of operations of } \\
\text { understanding the meaning of phraseologisms in children and } \\
\text { their use in speech }\end{array}$} & 3.5 & 22.6 & 47.7 & 26.2 \\
\hline
\end{tabular}




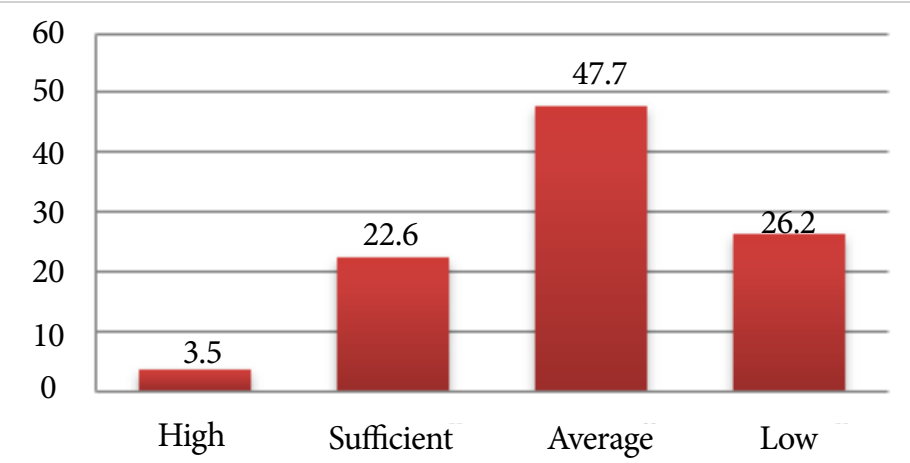

Figure 8. Levels of development of children's operations of understanding the meaning of phraseologisms and their use in speech

It was established that each level of development of operations of understanding the figurative meaning of phraseological units and their use in speech is correlated with certain psychological and psycholinguistic characteristics.

The high level of development of operations (4148 points) includes children (3.5\%), in whom the operations of understanding the figurative meaning of phraseological units and operations of using phraseological units in speech are fully developed. Pre-schoolers not only understand the figurative meaning, but also try to explain it, but in a unique way, typical of children of this age (explain figurative meaning by revealing the meaning of phraseologisms with specific examples, which is one of the direct manifestations of generalised figurative meaning particular phraseological unit; describe the phraseologism closely to the correct interpretation; replace phraseologism with a synonymous phrase). Children actively operationalise phraseological structures in spontaneous speech, use them grammatically correctly, do not change their established form, accurately actualise them in spontaneous speech. Children's speech is characterised by pronounced emotionality, it is emotionally coloured in expressive and figurative terms, contains phraseologisms with words-concepts. In the statements of pre-schoolers, approving and disapproving characteristics can be traced by means of phraseological structures.

A sufficient level of development of operations (2840 points) includes children (22.6\%), in which operations of understanding the meaning of phraseologisms and their use in speech are partially developed. These children understand phraseologisms in the literal sense, and also reveal the figurative meaning of phraseological units not by self-interpretation, but only by choosing a variant of meaning from the functional equivalents given to them. Preschoolers actualise phraseological units in speech mainly in the situation of the educator's request to use unusual expressions during the retelling of a fairy tale; reproduce phraseology in the established form; use phraseologisms accurately. Children are able to evaluate the actions of peers, to give approving or disapproving characteristics by means of phraseologisms, but the evaluation of speech is nominated mostly by negative, stylistically underestimated characteristics. Pre-schoolers express the emotionality of speech with the help of phraseological compounds that reproduce emotional states (admiration, joy, surprise, resentment, confusion).

The average level of development of operations
(19-27 points) includes $47.7 \%$ of children with minimally developed operations of understanding the meaning of phraseologisms and their use in speech. These children do not understand the figurative meaning of phraseologisms, but in a situation of additional stimulation (choosing a variant of the meaning of the proposed) choose both figurative and associative meanings. Pre-schoolers explain phraseological units in the process of retelling fairy tales and only in situations where the educator reminds them of the need to use unusual expressions. By reproducing phraseological structures, children usually change their established forms through reduction and transformation. Children belonging to this group operationalise phraseologisms inappropriately in different speech situations. Evaluations and emotionality are not traced in expressions. The figurativeness of speech is determined by the phraseological structures heard from fairy tales and used during their retelling.

The low level of development of operations (018 points) includes children $(26.2 \%)$, in which operations of understanding the meaning of phraseologisms and their use in speech are undeveloped. These children understand neither the figurative nor the direct meaning of phraseologisms. In a situation of additional stimulation, they choose both associative and semantically abnormal meanings. This group also includes respondents who do not communicate with the educator/psychologist. There are no phraseologisms in children's speech.

The study made it possible to record the difficulties associated with deciphering the figurative meaning of phraseologisms and their verbalisation in speech, namely: a) the difficulty of inhibiting the nominative meanings of individual words that form the phraseological structure; b) difficulties of abstraction from external (accidental) associations; c) difficulties in explaining figurative meanings of phraseological units in spontaneous speech.

The authors of the study believe that the causes of these difficulties are the underdevelopment of children's speech and cognitive operations, namely: underdevelopment of metaphorisation, "deactualisation" of the components of phraseological units (transposition of semes); undeveloped operations of semantic syntax and choice of linguistic meanings of words; undeveloped operations of secondary semiosis, when the finished phrase (phraseologism) is used to denote another meaning; underdevelopment of comprehension operations; undeveloped operations of 
inhibition of side associations, which cause inaccurate, incorrect understanding of the meaning of phraseologisms; underdevelopment of operations of abstraction from the denotative meaning of individual words, from which a coherent phraseological expression is formed; limited language and speech experience of children; limited life experience of children; dominance of visual-sensory impressions and concrete-figurative thinking over abstract and verbal-logical thinking; underdevelopment of operations of memorising phraseologisms and keeping them in memory. Additionally, a significant reason for the emergence of these difficulties in children is that in preschool education still not enough attention is paid to the purposeful development of children's operations to understand the figurative meaning of phraseologisms, as well as to work to enrich children's speech with phraseological expressions and use these persistent colorful, witty and accurate expressions in communication. Thus, pre-schoolers occasionally perceive phraseologisms in the environment of preschool (perhaps in the family environment, in the surrounding reality); they do not have any practice of systematic explication (use) of phraseologisms in spontaneous speech (due to the lack of appropriate purposeful work in the preschool, specially created situations that would stimulate children to express themselves using phraseologisms), which leads to the fact that most perceived and meaningful expressions "shift" into the passive speech of pre-schoolers.

\section{CONCLUSIONS}

Pre-schoolers acquire the phraseologisms of their native language spontaneously, under the influence of the speech of others (by imitating the language of adults, repeating interesting and unusual expressions), and selectively (children use simple phraseologisms in speech, which are accessible to understanding, close to their life experience). Pre-schoolers understand the meaning of phraseologisms better than use them in oral speech. The use of phraseologisms in spontaneous speech is a more complex speech operation for children than the operation of deciphering the figurative meaning of phraseologisms. The authors of this study explain this by the fact that in the senior preschool age the active vocabulary of children is being enriched (including phraseologisms heard from adults in everyday life in certain situations), at the same time most phraseological structures shift into the passive vocabulary of children. The phraseology of pre-schoolers is stylistically homogeneous, it is represented only by those phraseological structures that are most often used by both adults and children.

The study showed that both the operations of children's understanding of the figurative meaning of phraseological units and the operations of using phraseological units in spontaneous speech have an individual character. Children understand the meanings of phraseologisms differently and use them differently in speech.

Thus, the study allowed us to assert that both operations of understanding the figurative meaning of phraseological units and operations of using phraseological units in spontaneous speech are still at the stage of formation and require further development in older preschool children. The authors of this study see prospects for further research in the development and testing of psychotechnologies for the purposeful formation of operations in children of older preschool age to understand the figurative meaning of phraseologisms and their use in speech.

\section{REFERENCES}

[1] Gvozdev, A.N. (1961). Issues in the study of children's speech. Moscow: Izd-vo APN RSFSR.

[2] Mysan, I.V. (2012). The use of phraseology in the development of colourit of the speech. In Pre-primary and primary education: Achievements, challenges, prospects: Materials of the scientific conference (pp. 110-112). Mukachevo: MDU.

[3] Kharchenko, V.K. (1987). Semantics of the word in children's speech: Problems and observations. In Children's speech as a subject of linguistic study (pp. 23-34). Leningrad.

[4] Artemyeva, T.V. (2013). Peculiarities of primary school children figurative speech comprehension. World Applied Sciences Journal, 27(6), 738-741. doi: 10.5829/idosi.wasj.2013.27.06.13709.

[5] Eliseeva, N., \& Gorobets, E. (2017). Perception of idioms by Russian-speaking children: Materials for a neurolinguistic questionnaire. Philology and Culture, 4(50), 16-21.

[6] Mitkina, I.N. (2002). Mastering phraseology of the older preschool children. In Developing Children's speech: Traditions and Perspectives: Materials of the conference (pp. 47-48). Moscow: Izd. RAO.

[7] Eliseeva, N., Guts, E.N., \& Marin, A. (2017). Comprehension of idiomatic expressions by Russian speaking typically developing children. Psychology in Russia: State of the Art, 10(4), 22-32. doi: 10.11621/pir.2017.0403.

[8] Abrahamsen, E.P., \& Burke-Williams, D. (2004). Comprehension of idioms by children with learning disabilities: Metaphoric transparency and syntactic frozenness. Journal of Psycholinguistic Research, 33, 203-215.

[9] Oakhill, J., Cain, K., \& Nesi, B. (2016). Understanding of idiomatic expressions in contextin skilled and less-skilled comprehenders: Online processing and interpretation. Scientific Studies of Reading, 20(2), 124-139.

[10] Cain, K., Oakhill, J., \& Lemmon, K. (2005). The relation between children's reading comprehension level and their comprehension of idioms. Journal of Experimental Child Psychology, 90, 65-87. doi: 10.1016/j.jecp.2004.09.003.

[11] Cain, K., Towse, A.S., \& Knight, R.S. (2009). The development of idiom comprehension: An investigation of semantic and contextual processing skills. Journal of Experimental Child Psychology, 102, 280-298. doi: 10.1016/j.jecp.2008.08.001.

[12] Vosniadou, S., \& Ortony, A. (1986). Testing the metaphoric competence of the young child: Paraphrase vs. Enactment. Human Development, 29, 226-230.

[13] Gibbs, R. (1987). Linguistic factors in children's understanding of idioms. Journal of Child Language, 14(3), 569-586. doi: 10.1017/S0305000900010291. 
[14] Caillies, S., \& Le Sourn-Bissaoui, S. (2006). Idiom comprehension in French children: A cock-and-bull story. European Journal of Developmental Psychology, 3(2), 189-206. doi: 10.1080/17405620500412325.

[15] Levorato, M.C., \& Cacciari, C. (1992). Children's comprehension and production of idioms - the role of context and familiarity. Journal of Child Language, 19(2), 415-433. doi: 10.1017/S0305000900011478.

[16] Chiappe, D.L., \& Chiappe, P. (2007). The role of working memory in metaphor production and comprehension. Journal of Memory and Language, 56, 172-188. doi: 10.1016/j.jml.2006.11.006.

[17] Caillies, S., \& Le Sourn-Bissaoui, S. (2008). Children's understanding of idioms and theory of mind development. Developmental Science, 11, 703-711. doi: 10.1111/j.1467-7687.2008.00720.x.

[18] Pearson, B.Z. (1990). The comprehension of metaphor by preschool children. Journal of Child Language, 17, $185-203$.

[19] Vygotsky, L.S. (1999). Thought and language. Moscow: Labirint.

[20] Akhutina, T.V. (2002). Neurolinguistic analysis of dynamic aphasia. On the mechanisms of building the utterance. Moscow: Terevinf.

[21] Belobrykina, O.A. (1998). Speech and communication. Jaroslavl: Akademija razvitija.

[22] Vitt, N.V. (1985). Emotional regulation of speech and thought processes. In Psychological and psychophysiological studies of speech (pp. 123-136). Moscow: Nauka.

[23] Kalmykova, L.O. (2008). The psychology of speech activity formation in pre-school children. Kyiv: Feniks.

[24] Uzhchenko, V.D., \& Uzhchenko, D.V. (2007). Phraseology of the modern Ukrainian language. Kyiv: Znannja.

[25] Kalmykova, L., \& Mysan, I. (2014). Psycholinguistic aspects of phraseology as theoretical and methodological foundations of children's speech enriching. East European Journal of Psycholinguistics, 1, 66-74.

\author{
Наталія Валентинівна Харченко, Інна Володимирівна Мисан \\ Університет Григорія Сковороди в Переяславі \\ 08401, вул. Сухомлинського, 30, м. Переяслав, Україна
}

\title{
Психолінгвістичне вивчення мовлення дітей старшого дошкільного віку: особливості розуміння значення фразеологізмів і вживання їх у спонтанному мовленні
}

\begin{abstract}
Анотація. Оволодіння фразеологією рідної мови важливе для мовленнєвого та психічного розвитку дошкільників; за допомогою фразеологізмів діти можуть експресивно відтворювати в мовленні різноманітні соціальні події, неупереджено характеризувати людей, їхні дії та вчинки. Мета наукової роботи - вивчити психолінгвістичні особливості розвитку в дітей операцій розуміння переносного значення фразеологізмів і вербалізації їх у спонтанному мовленні. 3 цією метою використовувалися методи оцінювання розуміння переносного значення приказок і метафор, прямого тлумачення слова, вибору одного варіанта значення із кількох парафраз, опитування дітей, фіксація їхніх висловлювань на диктофоні, бесіди з дітьми. Аналіз мовлення дітей відбувався за критеріями та відповідними показниками: семантичний (лексичний, метафоричний, концептуальний), прагматичний (активність вживання фразеологізмів, правильність відтворення, доречність актуалізації), експресивно-стилістичний (оцінність, емоційність, образність мовлення). За результатами дослідження було виокремлено чотири рівня розвитку в дітей операцій розуміння переносного значення фразеологізмів і вживання ïx у мовленні: високий, достатній, середній, низький, кожен з яких співвідносився 3 певними психологічними та психолінгвістичними характеристиками. Встановлено, що оволодіння дітьми фразеологією відбувається стихійно, під впливом мовлення оточуючих, та вибірково. 3’ясовано, що дошкільники краще розуміють значення фразеологізмів, ніж уживають їх в усному мовленні; виявлено, що використання фразеологізмів у спонтанному мовленні є для дітей складнішою мовленнєвою операцією, ніж операція декодування переносного значення фразеологізму. Проте, і операції розуміння переносного значення фразеологізмів, і операції експлікування фразеологізмів у спонтанному мовленні потребують подальшого розвитку. Практична цінність дослідження полягає у розробленні діагностувальної методики вивчення операцій розуміння значення фразеологізмів та їхнього вживання у спонтанному мовленні в зоні актуального мовленнєво-мисленнєвого розвитку дитини
\end{abstract}

Ключові слова: розуміння переносного значення фразеологізмів, експлікування фразеологізмів, студіювання мовлення, фразеологічні одиниці 